\title{
Small-scale marine fisheries in the municipal district of Florianópolis, Santa Catarina, Brazil
}

\author{
Bastos, GC. ${ }^{\text {** }}$ and Petrere Jr., M. ${ }^{\mathrm{b} *}$ \\ ${ }^{a}$ Centro de Recursos Hídricos e Ecologia Aplicada - CRHEA, Universidade de São Paulo - USP, \\ Rod. Domingos Inocentini, Km 13,5, CEP 13530-000, Itirapina, SP, Brazil \\ ${ }^{\text {b} D e p a r t a m e n t o ~ d e ~ E c o l o g i a, ~ U n i v e r s i d a d e ~ E s t a d u a l ~ P a u l i s t a ~-~ U N E S P, ~}$ \\ Av. 24A, 1515, Bela Vista, CP 199, CEP 13506-900, Rio Claro, SP, Brazil \\ *e-mails: gildobas@onda.com.br, mpetrere@rc.unesp.br \\ Received July 14, 2009 - Accepted December 28, 2009 - Distributed November 30, 2010
}

(With 1 figure)

\begin{abstract}
The objective of this paper is to describe the main characteristics of small-scale marine fisheries in the municipal district of Florianópolis (SC), the capital city of the state of Santa Catarina. We give information about the most captured species, the fishing fleet and fishing gear used. The dynamics of the activity is described, considering the kind of operation of the boats, alongside post-capture procedures. The analyses were accomplished in two types of fishing communities: the one composed of fishers that fish in bays (North and South) and those who fish in the open sea. Numeric differences were observed among these two fishing areas, indicating the existence of two different fleets operating in the area. Differences between the two fishing areas were detected, considering the species caught, the harvest time and the fishing gear used. The open sea fishers have boats with dimensions, engine power, number of crew and fuel consumption numerically higher than those working in bays, indicating the existence of two distinct fleets operating in the region.
\end{abstract}

Keywords: marine small-scale fisheries, fishing dynamics, fishing gear, harvest season, Florianópolis.

\section{Pescarias marinhas de pequena escala no município de Florianópolis, Santa Catarina, Brasil}

\begin{abstract}
Resumo
Este trabalho teve como objetivo caracterizar a pesca de pequena escala no município de Florianópolis (SC). São apresentadas informações sobre as principais espécies capturadas, sobre a frota e artes de pesca utilizadas, sobre a dinâmica da atividade, considerando a forma de operação das unidades produtivas, e sobre os procedimentos póscaptura adotados. As análises foram realizadas em dois tipos de comunidades pesqueiras: as compostas por pescadores que atuam em baías e aquelas cujos integrantes pescam em mar aberto. Foram detectadas diferenças entre as duas áreas de pesca considerando as espécies capturadas, as épocas de captura e as artes de pesca utilizadas. Os pescadores de mar aberto possuem embarcações com dimensões, potência dos motores, número de tripulantes e consumo de combustível numericamente superiores aos que atuam nas baías, indicando a existência de duas frotas distintas operando na região.
\end{abstract}

Palavras-chave: pesca marinha de pequena escala, dinâmica da pesca, artes de pesca, período de safra, Florianópolis.

\section{Introduction}

Fishing activity may be considered as the combination of different interacting components, including man, natural resources and management systems, influenced by internal and external factors. As such, fishing is composed of a group of interrelated activities, including capture, fish processing, the market and the consumer's demand for fish, operating on certain socioeconomic and political contexts (Salas and Gaertner, 2004).
Small-scale fishers use a wide range of gear and fishing techniques, catching large quantities of fish (Salas et al., 2007). The operation of the small-scale fishing fleet is constrained by environmental characteristics and the seasonal behaviour of the exploited resources.

In Florianopolis, various types of fishing gear are found, with a predominance of gillnets (anchorage, driftnet, etc.), as well as zangarilho to catch squids and beach seine 
to catch mullets. Fishers who work in the open sea use, preferably, specific gillnets for catching bluefish, croakers, mullet and codling, while those in the north and south bays employ driftnets for white shrimp and gillnets for fishes (SEAP, IBAMA and PROZEE, 2005).

In this paper we describe the main characteristics of the small-scale fisheries in Florianópolis (SC), aiming to detect differences in the fisheries accomplished by the communities whose members fish in bays and the ones who fish in the open sea.

\section{Study Area}

The municipal district of Florianópolis, capital of Santa Catarina State $\left(27^{\circ} 22^{\prime}\right.$ and $27^{\circ} 51^{\prime}$ S; 48 $20^{\circ}$ ' and $48^{\circ} 37^{\prime} \mathrm{W}$ ) is divided between a continental portion, with an area of $12.1 \mathrm{~km}^{2}$, and an insular portion (Island of Santa Catarina), of $424.4 \mathrm{~km}^{2}$ (Figure 1). The island is separated from the continent by a $500 \mathrm{~m}$ strait, with an average depth of $28 \mathrm{~m}$, forming two bays: north and south. Its shoreline has $172 \mathrm{~km}$ of coast, quite irregular, and is composed of bays and lagoons (Nascimento, 2002). The morphological characteristics favour the settlement of fishing nuclei (Lago, 1961).

Fishers who operate in the bays are found in several spots along the adjacent coast, where small fishing ranches used to keep boats and gear are observed. Except Sambaqui and Saco Grande, which concentrate a larger amount of fishers, in other spots their spatial distribution is more diffuse. Old fishing communities had to be displaced following road construction along the coastline of Santa Catarina Island facing the bays. On the other hand, fishers who operate in the open sea have their communities located in specific points of the coast, having good urban infrastructure, which, during the summer, are much sought out by tourists.

\section{Material and Methods}

\subsection{Data collection}

The fishing communities were classified into two categories:

i) communities where the fishers operate in the open sea; and

ii) communities where the fishers operate in two bays: North and South. In the two groups, for ease of access, the following fish communities were selected:

1) Ponta das Canas, Ingleses, Barra da Lagoa, Armação and Pântano do Sul; and

2) Sambaqui and Saco Grande (main nuclei) and some fisher's camps located in Baía Norte, Saco dos Limões and Costeira.

Three data collection campaigns were accomplished during 2008.

The campaigns consisted of visits to different fishing communities, where the fishers present at the site were interviewed and indicated others to be interviewed later, according to the "snowball" methodology (Camargo and Petrere (2001), Cetra and Petrere (2001), Ceregato and Petrere (2003) and Petrere et al. (2006). The data were stored on a specific database and their statistics (mean, median, standard deviation and frequency distributions) were calculated.

\section{Results}

We interviewed 218 fishers, 67 fishing in the bays and 151 in the open sea.

\subsection{Captured species}

Table 1 lists the main commercial species captured by fishing area (bay/open sea), informed by the fishers. The frequencies correspond to the percentile of interviewees that listed the species among the most frequent. The species that were mentioned by less than $10 \%$ of interviewees were grouped in the category "other species". For the bays, this category includes several species: grunts (corcorocas) Haemulon spp. and Pomadasys spp., corocoro grunt (corcoroca) Orthopristis ruber (Cuvier, 1830), kingcroakers (papa-terras) Menticirrhus spp., American harvestfish (gordinho) Peprilus paru (Linnaeus, 1758), black drum (miraguaia) Pogonias cromis (Linnaeus, 1766), bluefish (anchova/anchoveta) Pomatomus saltatrix (Linnaeus, 1766), mojarras (carapicu) Eucinostomus spp., Brazilian

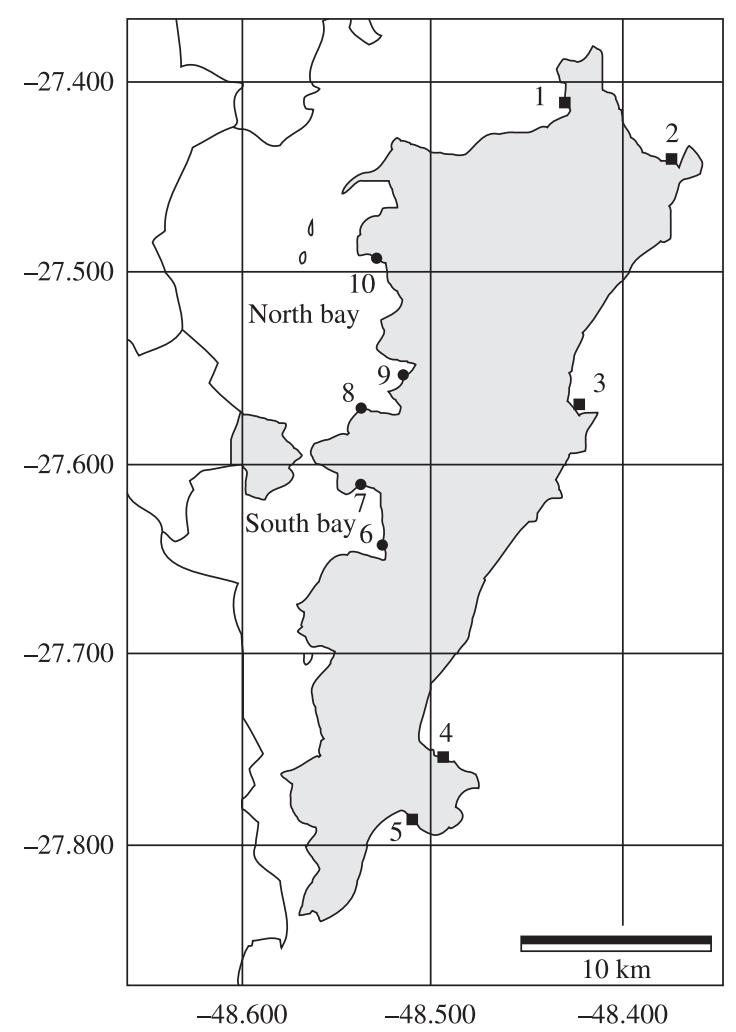

Figure 1. Municipality of Florianópolis (hatched). Black circles $=$ bay fishers and black squares $=$ open sea fishers. Communities: 1) Ponta das Canas; 2) Ingleses; 3) Barra da Lagoa; 4) Armação; 5) Pântano do Sul; 6) Costeira; 7) Saco dos Limões; 8) Baía Norte; 9) Saco Grande; and 10) Sambaqui. 
mojarra (caratinga) Eugerres brasilianus (Cuvier, 1830), largehead hairtail (espada) Trichiurus lepturus Linnaeus, 1758, king weakfish (pescadinha) Macrodon ancylodon (Bloch \& Schneider, 1801) and left-eye flounders (linguados) (Bothidae family). In the open sea, those fished include the Brazilian guitarfish (raia-viola) Rhinobatos horkelli Müller \& Henle, 1841, king weakfish Macrodon ancylodon (Bloch $\&$ Schneider, 1801) and some species of sharks (cações), shrimps (camarões), snooks (robalos) Centropomus spp., left-eye flounders, small mullets (paratis) Mugil spp. and groupers (garoupas) Epinephelus spp.

Table 1 also presents the periods of higher catches per species. Some are caught throughout the year, while others exhibit marked seasonal landings. According to the interviewees, the white shrimp (camarão-branco) Litopenaeus schimitti Burkenroad, 1938, the croaker (corvina) Micropogonias furnieri (Desmares, 1823), the catfish (bagre) (family Ariidae) and the largehead hairtail (espada) Trichiurus lepturus Linnaeus, 1758, in spite of presenting larger capture in some months, are caught every month, while the mullet (tainha) (Mugil spp.), the codling (abrótea) Urophycis brasiliensis (Kaup, 1858) and U. cirrata (Goode \& Bean, 1878), the squid (lula) (several species) and the bluefish (anchova) Pomatomus saltatrix (Linnaeus, 1766) are highly seasonal.

\subsection{The fishing fleet}

From 218 fishers, 129 (59\%) informed that they possess at least one boat, totalling a fleet of 151 boats, 64 operating in the bays and 87 in the open sea. Most of the fishers (85\%, $\mathrm{n}=129$ ) own only one boat for fishing. However, some fishers also have small support boats, not used directly for fishing, but just for reaching the main boat, anchored away from the beaches. All boats have a wooden hull, about $80 \%$ are motorised, most with centered motors $(76 \%, \mathrm{n}=121)$ using diesel as fuel $(95 \%, \mathrm{n}=98)$. Table 2 presents some characteristics according to its fishing area.

\subsection{Fishing gears}

The local fishers tend to use a wide range of gear, according to the available fish species, varying seasonally. Table 3 presents the main nets (and their dimensions), employed in the two fishing areas.

The nets most used by the interviewed fishers have three distinct modes of operation: 1) anchored nets, which are gillnets (fish are caught in the meshes) set at the bottom and left fishing for a period of time at sea,

Table 1. Most caught species and their harvest times, in accordance with the interviewees. The (\%) symbol refers to the percentage of interviewees who mentioned the species and $(n)$ is the number of interviewees.

\begin{tabular}{|c|c|c|c|c|c|}
\hline \multicolumn{3}{|c|}{ Bays $(n=45)$} & \multicolumn{3}{|c|}{ Open sea $(n=98)$} \\
\hline Species & $\%$ & Harvest time & Species & $\%$ & Harvest time \\
\hline $\begin{array}{l}\text { White shrimp } \\
\text { Camarão-branco }\end{array}$ & 49 & April to July & $\begin{array}{l}\text { Croaker } \\
\text { Corvina }\end{array}$ & 70 & All year \\
\hline $\begin{array}{l}\text { Croaker } \\
\text { Corvina }\end{array}$ & 47 & March to October & $\begin{array}{l}\text { Bluefish } \\
\text { Anchova }\end{array}$ & 68 & July to November \\
\hline $\begin{array}{l}\text { Small mullets } \\
\text { Parati }\end{array}$ & 42 & All year & $\begin{array}{l}\text { Mullets } \\
\text { Tainha/tainhota }\end{array}$ & 58 & May to June \\
\hline $\begin{array}{l}\text { Mullet } \\
\text { Tainha/tainhota }\end{array}$ & 33 & All year & $\begin{array}{l}\text { Codling } \\
\text { Abrótea }\end{array}$ & 15 & June to August \\
\hline $\begin{array}{l}\text { Shrimps (others species) } \\
\text { Camarão }\end{array}$ & 18 & All year & $\begin{array}{l}\text { Largehead hairtail } \\
\text { Espada }\end{array}$ & 12 & December to March \\
\hline $\begin{array}{l}\text { Catfishes } \\
\text { Bagres }\end{array}$ & 16 & $\begin{array}{l}\text { September to } \\
\text { December }\end{array}$ & $\begin{array}{l}\text { Squid } \\
\text { Lula }\end{array}$ & 12 & December to February \\
\hline Other species & 29 & All year & Others species & 10 & All year \\
\hline
\end{tabular}

Table 2. Average values for the length of boats, engine power and fuel consumption per trip, per fishing area. (S) is the standard deviation and $(\mathrm{n})$ is the number of interviewees.

\begin{tabular}{llcccc}
\hline & & Mean & Median & S & n \\
\hline Length (metre) & Bay & 7.17 & 7.50 & 1.49 & 57 \\
& Open sea & 9.03 & 9.10 & 2.51 & 66 \\
\hline Engine power (HP) & Bay & 15 & 11 & 14.20 & 38 \\
& Open sea & 48 & 45 & 40.42 & 52 \\
\hline Fuel consumption per trip (litre) & Bay & 7 & 6 & 5.99 & 46 \\
& Open sea & 30 & 30 & 21.31 & 51 \\
\hline
\end{tabular}


Table 3. Main nets utilised by the fishers, their length and height (in braças -1 braça $\approx 1.80$ metres) and their meshes (in $\mathrm{cm}$ ), per fishing area. (S) is the standard deviation and (n) is the number of interviewees.

\begin{tabular}{|c|c|c|c|c|c|c|}
\hline & & & Mean & Median & $\mathbf{S}$ & n \\
\hline \multirow[t]{12}{*}{ Bays } & Shrimp driftnet & Length & 494 & 400 & 180.35 & 19 \\
\hline & Mesh 5 to 7 & Height & 3 & 3 & 0.81 & 19 \\
\hline & Mullet net & Length & 362 & 382.76 & 109.90 & 5 \\
\hline & Mesh 11 & Height & 4 & 5 & 2.43 & 5 \\
\hline & Trammel net & Length & 619 & 400 & 699.92 & 23 \\
\hline & Mesh 8 to 12 & Height & 2 & 2.5 & 1.12 & 23 \\
\hline & Anchored gillnet & Length & 347 & 300 & 197.72 & 7 \\
\hline & Mesh 10 to 18 & Height & 3 & 2 & 0.92 & 7 \\
\hline & Driftnet & Length & 389 & 300 & 556.12 & 25 \\
\hline & Mesh 5 to 12 & Height & 2 & 2 & 0.88 & 25 \\
\hline & Encircling nets & Length & 407 & 400 & 117.01 & 7 \\
\hline & Mesh 7 and 8 & Height & 2 & 2 & 0.76 & 7 \\
\hline \multirow[t]{10}{*}{ Open sea } & Bluefish net & Length & 464 & 500 & 262.89 & 44 \\
\hline & Mesh 8 and 9 & Height & 8 & 8 & 2.59 & 43 \\
\hline & Mullet net & Length & 477 & 400 & 205.33 & 25 \\
\hline & Mesh 10 and 11 & Height & 23 & 25 & 7.97 & 24 \\
\hline & Croaker net & Length & 2,726 & 2,532 & $1,483.99$ & 35 \\
\hline & Mesh 13 and 14 & Height & 2 & 2 & 0.45 & 34 \\
\hline & Codling net & Length & 1,123 & 1,000 & 955.70 & 19 \\
\hline & Mesh 10 and 11 & Height & 2 & 2 & 0.57 & 19 \\
\hline & Left-eyed flounder net & Length & 748 & 775 & 348.10 & 8 \\
\hline & Mesh 18 and 20 & Heigth & 2 & 2 & 0.58 & 8 \\
\hline
\end{tabular}

and periodically checked by the fishers to remove the fish caught. In this group are the codling and the left-eye flounder nets, in the open sea, and anchored gillnets, in the bays. 2) driftnets, which are thrown adrift, kept close to the surface by floats, for catching fish after visualising the schools. In this group are the croaker and bluefish, in open sea, and the driftnets and shrimp driftnet, in the bays. The latter is thrown into the sea and moves in accordance to the movement of the tide and shrimp harvested are not previously seen by the fisher. 3) Encircling nets, which surround the schools and are closed for catching the fish. In this group are the mullet nets, in two fishing areas, and encircling nets, in the bays.

The trammel net is a special type of net that has three pieces of net, unlike the others that have only one. They are employed as fixed and as driftnets.

In addition to the already mentioned nets, cast nets are used for shrimp (meshes 2.5 and $4 \mathrm{~cm}$ between opposite knots, in the two fishing areas), for fish (meshes 4 to $8 \mathrm{~cm}$ in the bays and 8 to $10 \mathrm{~cm}$, opposite knots, in the open sea) and for squid (mesh 2 and $3 \mathrm{~cm}$ ) in open sea. Longlines and fishhooks are also used, with prominence of longlines for catfish, in the bays and codling and grouper, in open sea. The zangarilho is formed of a set of hooks that catch the squids which are attracted up close to the boat by lights on board.

\subsection{Harvest season}

According to the interviewed fishers, the months of January and February present the lower catches, as in bays (mean of 439/kg/month/boat) and in the open sea (mean of $150 \mathrm{~kg} / \mathrm{month} / \mathrm{boat}$ ). For the open sea fisheries, the best months range from May to August (mean of $6,380 \mathrm{~kg} / \mathrm{month} / \mathrm{boat}$ ). For the bays fisheries, except for January and February, fish capturing is nearly even (mean of $570 \mathrm{~kg} / \mathrm{month} / \mathrm{boat}$ ).

It is observed that for the open sea, the better months coincide with the mullet, codling and bluefish harvests. The worst months, independent of the fishing area, occur in the summer, obliging fishers to dedicate themselves to tourism-related activities.

As we can see, the estimated monthly production in weight by the fishers presented a wide range, as many interviewees had difficulty or they didn't know how to inform these statistics, mainly due to strong inter-annual variability.

\subsection{Fishing dynamics}

As it is common in small-scale fisheries, fishing trips rarely exceed more than one day, the general rule being going out to sea and returning the same day or at the most, on the next day. Specifically the white shrimp fishery, accomplished by the bay fishers, is conditioned 
by the tides, and in some cases, there are two fishing trips in the same day.

Table 4 presents the characteristics of the activity, per fishing area, in relation to the number of fishing days/week, fishing hours/trip and the number of crew members.

\subsection{Post-capture procedures}

Nearly all fishers adopt the same post capture handling. In relation to the fish conservation on board, it is not a common practice to carry ice in the boats. Fishes are kept in natura until landing. Only in the summer, a few boats take ice on board for fish conservation. In these cases, the ice is supplied by the intermediaries and fish shops. When the fisher operates with a small boat, he may produce ice at home.

It is unusual for the fisher to keep the fish at home, except for small amounts of fish that do not command a good market price. All the fish is sold at landing to intermediaries or directly to fish markets or taken to fish restaurants. In the summer, tourists usually go to the beaches to buy fresh fish.

Usually, fish is sold raw to the intermediaries or to the fish markets, although the fish sold to the tourists may be eviscerated or even filleted trying to get better prices from small buyers.

\section{Discussion}

Due to their dispersion, it is difficult to census the small-scale fishers in the Municipal district of Florianópolis. Aggio et al. (2007) estimated between 1,050 and 1,500 the number of fishers in the North Bay, but included fishers coming from other municipal districts. Information supplied by the Colônia de Pescadores Z11 de Florianópolis, state that the total number of fishers is 6,000 , with no information available on active and inactive fishers.

In the bays, the white-shrimp stands out, while in the open sea, besides the croaker, the seasonal species such as the codling, bluefish and mullet are also important. As always, there is a marked seasonal component, with alterations over the year, regarding fishers, fishing gear and fishing tactics according to the most abundant species. This behaviour is much more striking in open sea fisheries.

Climate changes on the shores of Santa Catarina are associated to the passage, formation or intensification of cold fronts, with different consequences throughout the year (Rodrigues et al., 2004). Due to these alterations, migratory movements of fish are observed for some species of mullets, bluefishes and codlings. During the autumn/ winter period, schools of these species come close ashore, swimming along the coastline, being available to small scale fishers, mainly for the ones operating in the open sea, when higher catches take place. Squids and largehead hairtail are also important for the open sea fisheries when they are closer to the coastline.

The number of potential marketable commercial species is quite high but fisheries concentrate just on a few target species. This information is compatible to the official catch/effort information of the State of Santa Catarina (IBAMA, 2008), where the 12 most captured species (18\% of the total number of species) are responsible for $71 \%$ of the landed fish, in weight. In Florianópolis, in the localities of Barra da Lagoa, Ingleses and Pântano do Sul, Martins and Perez (2008) noted that in the small scale trap-fishing (cerco flutuante), despite the high number of species caught, this fishery is based on three species: largehead hairtail, squids and blue runner (manezinho) Caranx crysos (Mitchill, 1815).

The fish stock conditions the use of gear, with specific fishing techniques aiming to exploiting them, using fishers' inherited knowledge accumulated from previous generations. We may observe two types of fishing strategies: i) specialist, targeting the capture of specific fish species; and ii) generalist, where procedures are adopted for exploiting the available species (Diegues, 1983; Berkes et al., 2006; Ramires et al., 2007).

Although local fishers tend to use a wide range of gear, it is verified that the most common gear among open sea fishers, besides gillnets (which is employed for the most important species (croaker, mullet, bluefish and codling)), is the zangarilho in the squid fishing season. In both bays, the use of driftnet for shrimp is very common, while fish are caught with a higher variety of gear. The dimensions of the open sea gear are greater than those used in the bays. For the open sea, there exists fishing gear designed for catching certain fish species. This same feature is not observed in the bay fisheries: except for the driftnets used for shrimp fishery, their gear is less specialised, their catches presenting more species.

The utilisation of several fishing gears and fishing techniques, according to the available resource, was confirmed by other authors in the state of Santa Catarina.

Table 4. Number of fishing days/per week, fishing hours/day and crew number in each fishing area. (s) is the standard deviation and $(\mathrm{n})$ is the number of interviewees.

\begin{tabular}{llcccr}
\hline & & Mean & Median & s & n \\
\hline Fishing days/week & Bays & 5 & 5 & 1.34 & 54 \\
& Open sea & 6 & 7 & 1.76 & 100 \\
\hline Fishing hours/day & Bays & 9 & 10 & 3.16 & 51 \\
& Open sea & 11 & 12 & 3.06 & 99 \\
\hline Crew number & Bays & 2 & 2 & 0.56 & 54 \\
& Open sea & 4 & 4 & 1.40 & 100 \\
\hline
\end{tabular}


Rodrigues et al. (1998), in the Bay of Babitonga (SC), identified 4 main groups of fishing techniques: i) longlines and hooks; ii) trawl fisheries, iii) gillnetting fisheries; and iv) fish traps, presenting a wide variation in catch composition and in fish spots. Aggio et al. (2007) pointed to encircling nets, anchored gillnets and trawling as the gear most used in North Bay. Severo (2008) described the fishing techniques used by the fishers at Beach of Pinheira (SC), in some cases, similar to the ones described here. They listed them as: i) driftnets, mainly addressed to the bluefish, croaker and mullet; ii) anchored gillnet to codling, weakfishes (pescadas) Cynoscion spp., king weakfish and left-eye flounders; iii) encircling nets and trawling with canoes, for mullets; iv) beach seine for several fish species; and v) trawling for shrimp. Besides these main techniques, the author identified castnets and poles as secondary fishing techniques.

The dependency upon sazonal resources was also mentioned by other authors. Chavez et al. (2002) identified 5 migratory/seasonal species from the 15 species caught in the Bay of Guaratuba (PR). The same seasonal pattern of capture was identified by Freitas et al. (2002) in riverine communities in Central Amazon, correlated to environmental factors, and Ramirez et al. (2007) described the fish caught by some caiçara (marine coastal settlers) communities in the state of São Paulo. Martins and Perez (2008) identified a remarkable variation in the catches by gillnets and encircling nets in Florianópolis, related to the wind direction and presumably to the thermal structure of the water column.

The fishing capacity of a given fleet is a function of some of its basic attributes, such as the number of boats, their individual sizes and the time spent fishing (Batista, 2002). Besides the fishing power, differences in fish species composition can be a function of the boat dimensions (Almeida et al., 2001).

The boats operating in the open sea are larger, possessing more powerful engines consuming more fuel than those in the bays. Fishing area conditions, allied to the larger distances travelled to reach the fishing areas and the larger gear dimensions explain these differences. Even in the open sea fishing fleet there are smaller boats, in general fishing along the coastline. This finding was also observed by Martins and Perez (2008) who described boats with lengths varying from 5.5 to $11.0 \mathrm{~m}$ powered by $11-24 \mathrm{HP}$ engines in artisanal fish-trapping in Florianópolis.

In other sheltered zones of the coastline, as in Babitonga bay, the habitat favours smaller boats, with 2-fisher crews (Bastos, 2006). The same sort of boats are observed in the North and South bays. Boats with lengths varying from 5.4 to $8.0 \mathrm{~m}$ and between 4.78 and $8.71 \mathrm{~m}$ were observed respectively by Rodrigues et al. (1998) and Bastos (2006) in the Bay of Babitonga. In the same region, Rodrigues (2000) verified that $85.1 \%$ of the boats use motors between 3.5 and $20 \mathrm{HP}$ and Bastos (2006) observed that $75 \%$ have motors between 2 and $20 \mathrm{HP}$.

The time spent fishing is a function of the target species, which conditions the gear to be employed and fisher's strategy. The driftnet and encircling net demand the fisher's presence during fishing operations, while the use of surface or bottom fishing gillnets does not need their presence after the gear is set up in the appropriate spot. The open sea fishers are used to fishing for more days and more weeks when compared to the bays fishers, probably because they spend more time to find their fishing spots.

The average working days varies during the weeks, depending on the target species and stock abundance. During the interviews it was common to find fishers who informed the number of fishing days but they also informed that during certain periods of the year, depending on the harvest, they are used to fishing intensively or do not go fishing for more than one week. Bastos (2006) detected a variation from 4 to 6 fishing days in the week and from 7 to 10 hours of fishing a day, in the Babitonga Bay (SC). Jiménez-Badillo (2008) cites periods of 12 hours fishing per day among the fishers from Veracruz (Mexico).

The number of crew members in the open sea boats is larger than in the boats fishing in the two bays. The comparatively higher boat and net dimensions may be the determining factor for this difference. The crew size in open sea is compatible with other studies in similar fishing areas: 3 to 6 in the encircling net fishery in Florianópolis, depending of the spot (Martins and Perez, 2008) and 3 to 10 in the boats operating in the Beach of Pinheira (SC), depending on the fishing type (Severo, 2008)

The percentage of boats that adopt any fish conservation technique in the State of Santa Catarina, according to SEAP, IBAMA, and PROZEE (2005) is 70\%. Interviewed fishers informed that fish icing onboard is rare, due to the low temperatures in the harvesting season and fast transportation to the landing sites. The lack of fish conservation on board was observed by Jiménez-Badillo (2008) in Veracruz (Mexico), by Rodrigues et al. (1998) for some fishers of the Bay of Babitonga (SC) and by Severo (2008) in the Beach of Pinheira (SC). Bail and Branco (2007) observed that $49 \%$ of the shrimp fishers in Praia da Penha (SC) do not use any type of conservation and $42 \%$ just use ice.

It is considered that $77.5 \%$ of the fish caught and $100 \%$ of the shrimp are sold to intermediaries (SEAP, IBAMA, and PROZEE, 2005). It was informed that fish commercialisation is mostly performed by local intermediaries.

Finally the results here described allowed us to identify strong numerical differences, in most of the examined traits, in relation to the two fishing areas and the two fishing fleets.

Acknowledgements - This paper is part of the MSc dissertation of GCB supervised by MPJr at CHREA USP; We thank USP, UNESP and CNPq, for the facilities and financial support.

\section{References}

AGGIO, RBM., BAZZALLO, M., FLORES, PAC. and HANAZAKI, N., 2007. Pescadores, esforço de captura e espécies-alvo na pesca artesanal da Baía Norte Florianópolis, SC-BRASIL. In Anais do VIII Congresso de Ecologia do Brasil, 23 a 28 de setembro, 2007, Caxambu, MG. 
ALMEIDA, OT., McGRATH, DG. and RUFFINO, ML., 2001. The commercial fisheries of the lower Amazon: an economic analysis. Fisheries Management and Ecology, vol. 8, p. 253-269.

BAIL, GC. and BRANCO, JO., 2007. Pesca artesanal do camarãosete-barbas: uma caracterização socioeconômica na Penha (SC). Brazilian Journal of Aquatic Science and Technology, vol. 11, no. 2, p. 25-32.

BASTOS, GC., 2006. Atividade pesqueira na Baía da Babitonga. In CREMER, MJ., MORALES, PRD. and OLIVEIRA, TMN. Diagnóstico Ambiental da Baía da Babitonga. Joinville: Univille, p. $200-244$.

BATISTA, VS., 2002. Caracterização da frota pesqueira de Parintins, Itacoatiara e Manacapuru, Estado do Amazonas. Acta Amazonica, vol. 33, no. 2, p. 291-302.

BERKES, F., MAHON, R., McCONNEY, P., RICHARD, P. and POMEROY, R., 2006. Gestão da pesca de pequena escala: diretrizes e métodos alternativos. Rio Grande: Editora FURG. 360 p.

CAMARGO, SAF. and PETRERE, M., 2001. Social and financial aspects of the artisanal fisheries of Middle São Francisco River, Minas Gerais, Brazil. Fisheries Management and Ecology, vol. 8 , p. 163-171.

CEREGATO, SA. and PETRERE, M., 2003. Financial comparisons of the artisanal fisheries in Urubupungá complex in the middle Paraná river (Brazil). Brazilizan Journal of Biology, vol. 63, no. 4 , p. 673-682.

CETRA, M. and PETRERE, M., 2001. Small-scale fisheries in the middle River Tocantins, Imperatriz (MA), Brazil. Fisheries management and Ecology, vol. 8, p. 153-162.

CHAVES, P., PICHLER, H. and ROBERT, M., 2002. Biological, technical and socioeconomic aspects of the fishing activity in a Brazilian estuary. Journal of Fish Biology, vol. 61, Supplement A, p. 52-59.

DIEGUES, ACS., 1983. Pescadores, camponeses e trabalhadores do mar. São Paulo: Ática.

FREITAS, CEC., BATISTA, VS. and INHAMUNS, SJ., 2002. Strategies of small-scale fisheries on the Central Amazon floodplain. Acta Amazonica, vol. 32, no. 1, p. 101-108.

Instituto Brasileiro do Meio Ambiente e dos Recursos Naturais Renováveis - IBAMA, 2008. Estatística da pesca 2006 - Grandes Regiões e Unidades da Federação. Brasília, DF.

JIMÉNEZ-BADILLO, L., 2008. Management challenges of small-scale fishing communities in a protected reef system of Veracruz, Gulf of Mexico. Fisheries Management and Ecology, vol. 15 , p. 19-26.

LAGO, PFA., 1961. Contribuição geográfica ao estudo da pesca no litoral de Santa Catarina. Revista Brasileira de Geografia, vol. 1, p. 121-216.
MARTINS, RS. and PEREZ, JAA., 2008. Artisanal fish-trap fishery around Santa Catarina Island during spring/Summer: characteristics, species interactions and the influence of the winds on the catches. Boletim do Instituto de Pesca, vol. 34, no. 3, p. 413-423.

NASCIMENTO, RS., 2002. Atlas ambiental de Florianópolis. Florianópolis: Projeto Larus/UFSC, 80 p.

PETRERE, M., WALTER, T. and MINTE-VERA, CV., 2006. Income evaluation of small-scale fisheries in two Brazilian urban reservoirs: Represa Billings (SP) and Lago Paranoá (DF). Brazilizan Journal of Biology, vol. 646, no. 3, p. 817-828.

RAMIRES, M., MOLINA, SMG. and HANAZAKI, N., 2007. Etnoecologia caiçara: o conhecimento dos pescadores artesanais sobre aspectos ecológicos da pesca. Biotemas, vol. 20, no. 1, p. 101-113.

RODRIGUES, AMT., BRANCO, EJ., PEREIRA, MT., ZIMMERMANN, CE., RIBEIRO, GC., BRANCO, JO., KUROSHIMA, KN., CLEZAR, L., BRUTTO, LF., CREMER, MJ., SOUZA FILHO, MAC., HOSTIM SILVA, M., TOGNELLA, MMP., ALVES, S. and BELLOTTO, V.,1998. Manguezal da Baía da Babitonga. Brasília, DF: IBAMA, 145 p. Coleção Meio Ambiente, Série Estudos Pesca, vol. 25.

RODRIGUES, AMT., 2000. Diagnóstico Sócio-econômico e a Percepção Ambiental das Comunidades de Pescadores Artesanais do Entorno da Baía da Babitonga (SC): Um Subsídio ao Gerenciamento Costeiro. Florianópolis: Universidade Federal de Santa Catarina. 223 p. [Dissertação de Mestrado].

RODRIGUES, MLG., FRANCO, D. and SUGAHARA, S., 2004. Climatologia de frentes frias no litoral de Santa Catarina. Revista Brasileira de Geofísica, vol. 22, no. 2.

SALAS, S. and GAERTNER, D., 2004. The behavioural dynamics of fisheries: management implications. Fish and Fisheries, vol. 5, p. $153-167$.

SALAS, S., CHUENPAGDEE, R. SEIJO, JC. and CHARLES, A., 2007. Challenges in the assessment and management of smallscale fisheries in Latin America and the Caribbean. Fisheries Research, vol. 87, p. 5-16.

Secretaria Especial de Pesca e Aquicultura da Presidência da República - SEAP, Instituto Brasileiro do Meio Ambiente e dos Recursos Naturais Renováveis - IBAMA and Fundação de Amparo à Pesquisa de Recursos Vivos na Zona Econômica Exclusiva PROZEE, 2005. Relatório Técnico sobre o Censo Estrutural da Pesca Artesanal Marítima e Estuarina nos Estados do Espírito Santo, Rio de Janeiro, Paraná, Santa Catarina e Rio Grande do Sul. Itajaí. 151 p.

SEVERO, SM., 2008. Pesca artesanal em Santa Catarina: evolução e diferenciação dos pescadores da Praia da Pinheira. Porto Alegre: Faculdade de Ciências Econômicas, Universidade Federal do Rio Grande do Sul, 135 p. [Dissertação de Mestrado]. 
